\title{
Research on How to Improve the Quality of Education in Colleges and Universities under the Background of Big Data
}

\author{
Wan-Fang Liu, Wei-Dong Chang \\ Hunan Police Academy, Changsha, China \\ E-mail: Hnjcxy_lwf@163.com, 1026479891@qq.com
}

\begin{abstract}
The era of big data brings a lot of opportunities and challenges to college education. Combined the actual time in the open and reform, innovation under the guidance of concept, the paper has established information management system platform, the people-oriented management system, flexible degree management and total quality management mechanism for all kinds of big background data according to two aspects of university teaching management, key areas and its combination. The new management system in colleges and universities which is established is suit for large data of actual classroom teaching mode, individualized education and learning mechanism, the mechanism of the school semester full open, flexible, student evaluation mechanism, multiple education teaching methods combining mechanism such as a new education teaching mode of comprehensive innovation path to improve the quality of education also to promote the sustained long-term development of colleges and universities.
\end{abstract}

Keywords-Big Data; College Education; Quality of Education; Development Path

\section{INTRODUCTION}

With the rapid development of Internet technology and application in the $21 \mathrm{st}$ century, people entered an unprecedented era of big data. With the development and application of big data and its technology, people's life in all fields is changed; college education faces a profoundly impact and challenges. In this context, how to improve the teaching quality of college education and promote the healthy and long-term development of colleges and universities is an inevitable and major issues to be resolved. $^{[1]}$

\section{BIG DATA AND ITS TECHNOLOGY}

Big data is a result of the development of Internet and database technology. Big data is the huge scale of data collection which it's large scale to the generation, storage, management, analysis, far beyond the scope of traditional database software tool processing ability. It has four characteristics, just as data size, a variety of data types, fast data transmission and low density data value. With the advent of cloud, big data is becoming more and more attention by people and countries. In September 2008 Nature launched Big Data (Big Data) after the cover of the column, Big Data research upsurges prevailing in the academia and industry. In March 2012, the United States government proposed the "big data research and development plan", [2] this plan aims to improve human's ability to get useful knowledge from massive amounts of complex data, it marks that a big data has been raised to national strategic level. In September 2015, thechinese state council issued the action program of development data system deployment for promote the development of big data. $[3,4]$

Big data needs special technology to real-time processing vast amounts of data effectively, it goes with cloud computing which is a coin of two sides, including extensible storage system, the distributed file system, distributed database, parallel database, data mining power grid, the Internet, the Internet of things, and cloud computing platform. It's Processing data unit reaches TB and $\mathrm{PB}$.

\section{BIG DATA'S CHARACTERISTICS AND TRENDS UNDER THE BACKGROUND OF UNIVERSITY EDUCATION}

Science and technology are the basic elements of human existence, big data and its technology also will deeply influence the education in colleges and universities, and they conform to the characteristics of the era of big data in the education of colleges and universities. [5]

\section{A. Height Informatization of the College Education}

With the rapid development of science and technology, especially the IT technology, informatization education is a way to promote education innovation in colleges and universities which can improve the quality of education. In our country most massive information construction in colleges and universities began in the 90's, started relatively late compared than western developed countries, but after 20 years development, it has form the large-scale basic construction stage from the depth of information application system construction stage. Information technology has been widely used in colleges and universities' teaching, scientific research, management and other fields, which has good effect. According to the materials provided by computer and information management center of tsinghua university, tsinghua university, is currently 700 courses each semester, USES the network auxiliary teaching, the school has more than twenty thousand students through the network course.[6,7] Based on the big development of network distance education in our country, it is reported that in 1999 only four universities in our country began to distance education pilot, only more than 7000 students at first.[8] Now it has grown to 67 universities, a total of more than 
130 students. High degree of information era of big data increases in the number of channels to make the students to acquire knowledge, depth, width and speed, not restricted by time and place.

\section{B. Popularization of College Education}

In the Internet age, the ways and channels of unprecedented diversity, from which people obtain knowledge in colleges and universities is not the only way to knowledge acquisition, along with the rapid healthy steady economic development of our country at the same time, the increasing demand for high quality compound talents in all walks of life, necessary to continually expand the scale of enrollment in university, cultivating talents and meet the need of economic development to promote the school transformation from elite education to popular education. In 1978, China's higher education gross enrollment ratio is only $1.55 \%$, rose to $9.76 \%$ in 1998 . With University enrollment expansion from 1999, higher education gross enrollment ratio rising fast, in 2002 reached $15 \%$, popularization of higher education from elite education stage to stage. 2015 higher education gross enrollment rate reached $36 \%$, estimated at $40 \%$ in 2020. [9, 10]

\section{Open Education in Universities}

The rapid development of wireless Internet, Internet of things, as between the universities and colleges and universities, colleges and universities between various communications with the outside world offers unlimited convenience. [7]Big data era of new technology, new problems emerge in endlessly, frequent exchanges with the outside world more promote the colleges and universities. At the same time, the core of the modern university management should be open, open the school to make the school is full of vitality, constantly enhance the core competitiveness, behind closed doors, only bound feet. Colleges and universities in people, goods, content, sites, is open to students, society for all-round service. The big data and its technology will promote the development of colleges and universities to deep all-around open. [11]

\section{THE COLLEGE EDUCATION REFORM UNDER THE BACKGROUND OF BIG DATA PATH}

The arrival of the big data will inevitably influence and impact all aspects existing in university education, deduce the reform innovation continuously. Through reform and innovation in colleges and universities education which is suit for the era of big data, we can improv the college teaching quality and promoting the long-term health of people. Universities in its reform path is as follows: adhere to the open school-running concept under the guidance of the concept of innovation, reform the innovation from two aspects of management and education of colleges and universities teaching, set up all kinds of information management system platform in colleges and universities information depth application, establish the people-oriented management system, flexible degree management, total quality management system management system of colleges and universities, establish actual classroom teaching model, personalized education and learning mechanism, the mechanism of the school semester full open, flexible, student evaluation mechanism, multiple education teaching methods combining mechanism of new college education teaching methods suitable for large data. University management mechanism and characteristic of these is suitable for large data, the establishment of the education mechanism will improve the teaching quality of colleges and universities and the long-term development of colleges and universities. It's realization mode as shown in figure. 1. 


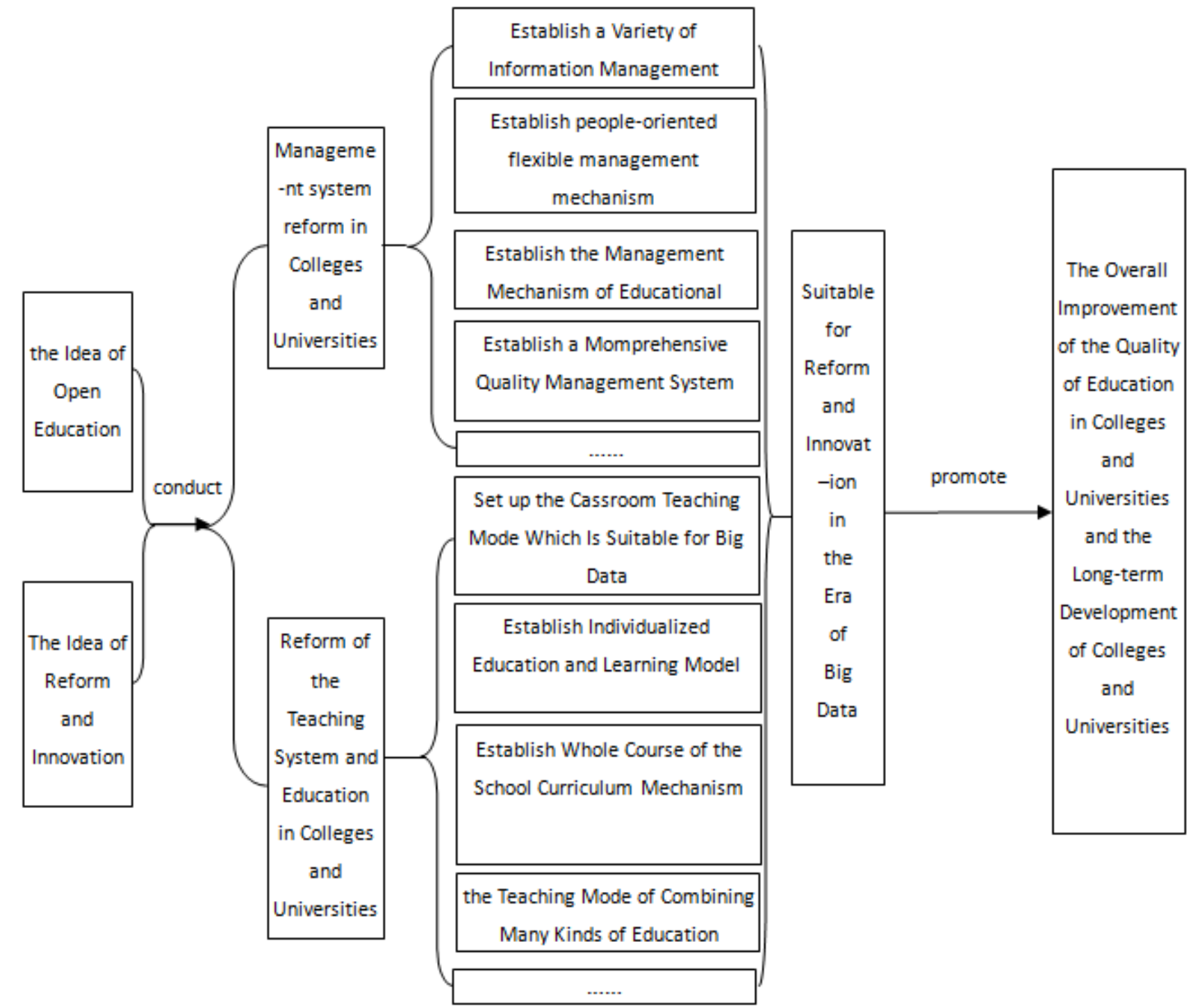

Figure 1 The Path Choice of Improving the Teaching Quality of Higher Education under the Background of Big Data

\section{V.INNOVATE MANAGEMENT SYSTEM TO IMPROVE THE QUALITY OF EDUCATION IN COLLEGES AND UNIVERSITIES}

There are much interference in colleges and universities such as administrative department of the government in the current management system of colleges and universities education.Because school internal administrative colour is too strong to promote school management mainly through administrative authority and the management process information is asymmetry, the main subjective initiative of college education is difficult to play. Many management institutions, bloated, eps shuffle, and efficiency are unsatisfactory. Teaching management is the core of university management in colleges and universities with the base, which is same machinery but ignore the disadvantages of teaching main body of human needs. This management system has been difficult to achieve the function of the colleges and universities under the background of big data management. [12]

\section{A. Establish All Kinds of Management System Platform On Deepening the Application}

With the further development of university informatization, the realization of various construction management function of application system has been established. It is necessary to manage work electronically as much as possible which includes establishing administrative office system, teaching management system, financial management, asset management system, scientific research management system management system, etc. College administrators take full advantage of the flexibility of data information management platform, interactivity and timeliness, completeness of information gathering system of school resources in the 
management and overall planning arrangements, reduce waste of resources, in a timely manner to make countermeasures. Making each functional departments, various colleges and universities in the colleges and universities teaching between synchronization and sharing of information resources, can strengthen the close link between universities and social reality, also can timely understand to the forefront of the dynamic teaching reform at home and abroad, which has realized the rapid integration of information resources sharing. To simplify the approval process, complete information interaction among departments, and improve the overall efficiency of management of colleges and universities is important.

\section{B. Establish People-Oriented Flexible Management Mechanism}

Since the founding of the people's common administrative centralization management pattern in colleges and universities, by go up and down, unified planning, rule-based, pay attention to efficiency is the main characteristic of this size. In a long time made great contribution for development of higher education in China. But as the big data era, the disadvantages of this management mode in colleges and universities is increasingly highlights: all subjects to the passive to complete the task, by the administrative authority to perform, lack of initiative and enthusiasm, is not conducive to innovation, more and more difficult to improve the quality of education in colleges and universities. To solve these problems with actual age establish people-oriented flexible management mode. This model is not a specific management mode, but the people-oriented management in colleges and universities, is essentially promote the development of the management main body for this, the greatest degree of meet the needs of the management main body, fully arouse the enthusiasm of the staff and students. Faculty, staff and students in colleges and universities are generally high quality high, reasonable whys and wherefores, self-control is strong, flexible management mechanism to build a harmonious relationship with colleagues and the relationship between teachers and students, form and helpful atmosphere of unity and cooperation, vigorously promote the improvement of teaching quality.

\section{Establish a Comprehensive Quality Management Refinement Mechanism}

The use of various management information platform in colleges and universities is beneficial to schools from the total quality management and fine management of enterprises. Total quality management (TQM), in the industrial and commercial enterprises to implement and has been a huge success. In 1994 the United States has more than four hundred institutions of higher education by implementing TQM. The known western higher education before the introduction of TQM is done meticulous argumentation and analysis. TQM with big data applications engineered to keep their suit management in colleges and universities reality, build a comprehensive education teaching quality in colleges and universities management standards. Big data technology can make faster to quantify various quality standards, fine, faster access to all the quality data in real-time. Through vast amounts of information mining, can find out the problems of the management of deviation, and immediate corrective measures. Total quality management refinement mechanism can promote the teaching innovation and the thorough, build the school brand, cultivate high-quality composite personnel, also can promote the work at all levels in the process of running school to achieve standardization, digital, institutionalize and program.

\section{Establish Students Flexible Degree Management Mechanism}

With the development of science and technology in big data era, the application of big data technologies will emerge in endlessly. College students have certain time to prepare for the business. It is allowed to extend the time of graduation in the management of colleges and universities for students in a semester in inventing, a business degree for flexible management mechanism, under the students to perform the application report. Due to the large data background, students access to the knowledge very much, the development and application of mobile network, so learning is not limited by time space. Diligent student can early completion of the course of learning, finish ahead of time, colleges and universities should make different degree of the elastic management mechanism to meet the demand of students' personalized learning. We should faster cultivate more talents for the society.

\section{INNOVATE EDUCATION TEACHING MECHANISM TO IMPROVE THE QUALITY OF EDUCATION IN COLLEGES AND UNIVERSITIES}

College students become useful are mainly through reasonable education teaching methods. The traditional classroom teaching is the teaching primarily, assuming the task of knowledge, solutions. Teacher is the classroom management and imparter of knowledge. Big data era background, the students acquire knowledge sources, the ways to solve questions are increasing, there are no restrictions on space and time, is that learners only of his own convenience. So the knowledge of one-way passive giving lectures is not adapted to the request of the ages.

\section{A. Establish Teaching Mode Suitable for Large Data of Actual Classroom}

Because of Internet teaching resource sharing and accessible, the rapid popularity of smartphones and make students acquire knowledge, solving problems mainly from the class and between the main body statuses have changed dramatically. It cause quite necessary to reform the traditional classroom teaching, which should be established for large data of actual classroom teaching mode. Such as turning classroom, virtual reality, and other forms of classroom teaching is exit. Flip the classroom pattern, the classroom teaching, applying virtual reality technology application can make teaching means to develop in the 
direction of scientific, effective, and fully mobilize students' learning enthusiasm, initiative, teachers became from the classroom administrators to planners, organizers and participants. Students become inspection field knowledge and knowledge application experiments.

\section{B. Establish a Personalized Education and Learning Model}

Big data era, due to the large Numbers of teaching resources sharing and network connectivity, making colleges and universities in the use of relevant mining algorithm, for students' learning habits, interests, hobbies, behaviors, such as historical data, develop the students' curriculum,learning and practice topic tracking personalized training plan and implementation. Personalized education essence is college teachers in the teaching process, purposeful, planned and organized the student individuality to get comprehensive development of the way of teaching, respect for the students' personality. Also to the development of students as the center, based on the students individual differences, it can develop targeted teaching goal, the selectivity of teaching content, diversity of teaching methods, promote the development of students personality completely. Individual students can choose according to their own habits, interest in learning courses, teachers to improve the education quality in colleges and universities.

\section{Establish the School Semester Opening Mechanism}

Due to the difference between personality and hobbies, learning attitude, effort, College students showed great differences in the learning process. In big data era due to the high degree of curriculum resource sharing, less time and space limit, colleges and universities can completely solve the studious that raw is not satisfied, slow can't eat. Through resource sharing, the structure adjustment of colleges and universities, education technology application can open all courses in the every semester, it can let the student choose any number of courses independently according to oneself circumstance to make the elastic education. Due to the development of technology, students complete the corresponding courses, curriculum goal, set the test at any time, which meet the needs of the students' individualized education.

\section{Build Multiple Education Methods of Combining The Teaching Mode}

In big data era, colleges and universities can provide students with more ways of learning by using education science and technology. That includes Off-job learning and workplace learning in cultivating way; have a face-to-face, online and offline teaching mode; electronic teaching, network teaching and teaching forms. In the process of students, it fully make use of the convenience of big data, immediacy, interactivity, multiple education methods of combining the teaching mode to meet the requirement of students' individualized learning and development, and improve the enthusiasm of the teaching body.

\section{SUMMARY}

Under the background of big data, the full development of information technology brings opportunities and challenges to the education of higher education. Improving the quality of higher education is a systematic project, only we seize the two aspects of higher education management and education teaching key areas and key links, combine with modern educational technology, reform and innovate with the background of the education management system and educational operation mechanism, can we make the reform and innovation becoming one of the effective ways and power of the higher education quality, and improve the full range of quality education in Colleges and universities, so colleges and universities can promote the long-term sustainable development.

\section{ACKNOWLEDGEMENT}

This research was financially supported by the 2016 annual open research foundation of Hunan Province, which is the Key Laboratory of network detection technology.

\section{REFERENCES}

[1] Mahsood Shah, Lucy Jarzabkowski, "The Australian higher education quality assurance framework", Perspectives: Policyand Practicein Higher Education, p. 173, 2013.

[2] Don Houston, Shelley Paewai, "Knowledge, Power and Meanings Shaping Quality Assurance in Higher Education: A Systemic Critique", Quality in Higher Education, p.193, 2013.

[3] Angela, Yung-chi Hou, Quality in cross-border higher education and challenges for the internationalization of national quality assurance agencies in the Asia-Pacific region: the Taiwanese experience" Studies in Higher Education, p.391, 2014.

[4] Sehriban Bugday Ince, Tatiana Gounko: "Quality assurance in Turkish higher education”, European Journal of Higher Education, p. 42, 2014.

[5] George O., Odhiambo, "Quality assurance for publichigher education: context, strategies and challenges in Kenya", Higher Education Research\& Development, p.335, 2014.

[6] Maha Mourad, 'Students' perception of quality assurance activities: Case study from the European higher education market", Sustainability Accounting, Management and Policy Journal, p43, 2013.

[7] Yingxia Cao, Xiaofan Li. "Quality and quality assurance in Chinese private higher education: A multi-dimension analysis and a proposed framework", Quality Assurance in Education, p.221, 2014.

[8] Rahel Schomaker, "Accreditation and quality assurance in the Egyptian higher education system", Quality Assurance in Education, p.232, 2015.

[9] Jordan C., M. Cheung, "Professionalism, profession and quality assurance practitioners in external quality assurance agencies in higher education", Quality in Higher Education, p. 212, 2015.

[10] Francis Ansah, "A strategic quality assurance framework kinan African higher education context", Quality in Higher Education, p.212, 2015.

[11] Stelian Andrei Bejan, Tero Janatuinen, Jouni Jurvelin, Susanne Klöpping, Heikki Malinen, Bernhard Minke, Radu Vacareanu, "Quality assurance and its impact from higher education in stitutions' perspectives: method logical approaches, experiences and expectations", Quality in Higher Education, p. 213, 2015.

[12] Angela Yung-Chi Hou, "Mutual recognition of quality assurance decisions on higher education institutions in three regions: alessonfor Asia”, Higher Education, p. 646, 2012. 